\title{
Two Cases of Cervical Emphysema after Tonsillectomy
}

\author{
Hyun-Gon Lim, Gi-Hwa Jung, Jae-Yol Lim, and Jeong-Seok Choi \\ Department of Otorhinolaryngology-Head and Neck Surgery, Inha University School of Medicine, Incheon, Korea
}

\section{편도 적출 수술 후에 발생한 경부 기종 2예}

임현곤 · 정기화 · 임재열 · 최정석

인하대학교 의과대학 이비인후-두경부외과학교실

\author{
Received April 17, 2014 \\ Revised June 9, 2014 \\ Accepted June 16, 2014 \\ Address for correspondence \\ Jeong-Seok Choi, MD \\ Department of Otorhinolaryngology- \\ Head and Neck Surgery, \\ Inha University School of Medicine, \\ 27 Inhang-ro, Jung-gu, \\ Incheon 400-711, Korea \\ Tel $+82-32-890-2438$ \\ Fax $+82-32-890-3580$ \\ E-mail jschoi@inha.ac.kr
}

Although tonsillectomy is a common surgical procedure in the otolaryngological department, subcutaneous emphysema after tonsillectomy is a rare complication. While most of the cases are benign and self-limiting, severe sequelae, such as tracheal compression, pneumopericardium, are possible. We present two patients with cervical emphysema after tonsillectomy, and focus on explaining the possible pathologic mechanisms, diagnosis, appropriate management, and nature course of cervical emphysema after tonsillectomy.

Korean J Otorhinolaryngol-Head Neck Surg 2015;58(4):267-70

Key Words Cervical emphysema - Complication · Pneumomediastinum - Tonsillectomy.

\section{서 론}

편도 적출 수술은 이비인후과 영역에서 흔히 행해지는 수 술로서 상대적으로 안전한 수술적 술기에 포함이 되나 편도 적출 수술의 합병증은 매우 다양하게 보고되고 있다. 일반적 으로 흔하게 발생할 수 있는 합병증으로는 수술 중 혹은 수 술 후 나타나는 출혈을 포함하여 이밖에 치아 손상, 이통, 인 후통 및 연하통, 그리고 구역감 및 구토 등이 있다.1) 또한 수 술 후 발생하는 경부 기종(cervical emphysema) 및 종격동기 종(pneumomediastinum)이 편도 적출 수술 후 합병증으로 발 생할 수 있으며 이는 매우 드물게 보고 되고 있다. ${ }^{2,3)}$ 비록 이는 일반적으로 치료가 용이하며 제한적인 합병증이긴 하나 적 절한 진단과 치료를 받지 않을 시 기관 압박(tracheal compression), 심막기종(pneumopericardium), 정맥 환류 이상(impaired venous return) 및 치명적 저혈압(fatal hypotension) 등 대 단히 심각한 결과를 낳을 수 있다는 점에서 매우 중요하다. ${ }^{4)}$ 저자들은 편도 적출 수술 후에 발생한 경부 기종 2예를 경 험하였기에 이 합병증에 대한 병태학적 원리, 환자에 대한 적절
한 진단과 치료에 대해 문헌 고찰과 함께 보고하고자 한다.

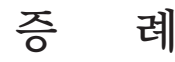

\section{증 례 1}

58세 여자 환자가 본원 일반외과에서 우측 유방암을 진단 받고 전신 전이 검사를 위해 시행한 양전자방출단층촬영 결 과 우측 편도에서 불소화 포도당(fluorodeoxyglucose)의 섭 취 증가를 보여 본과로 협진 의뢰되었다. 이에 우측 편도 조 직검사를 위해 전기소작술을 이용하여 우측 편도 적출 수술 을 시행하다. 환자는 수술 후 지속적인 인후통을 호소하고 있었고 수술 후 3일째 우측 경부의 부종을 함께 호소하였다. 신체검사 결과 우측 경부 부종과 함께 마찰음이 관찰되었으나 우측 편도 적출 수술 부위에는 특이 소견은 없었다.

우측 경부의 부종과 마찰음에 대해 경부 컴퓨터단층촬영 을 시행하였고 그 결과 우측 인두 주위 공간, 우측 아래 턱밑 공간 및 상부 기관주위로 다발성 공기 음영이 관찰되었다 (Fig. 1). 그리고 우측 편도 적출 수술 부위에 조직의 결함으 

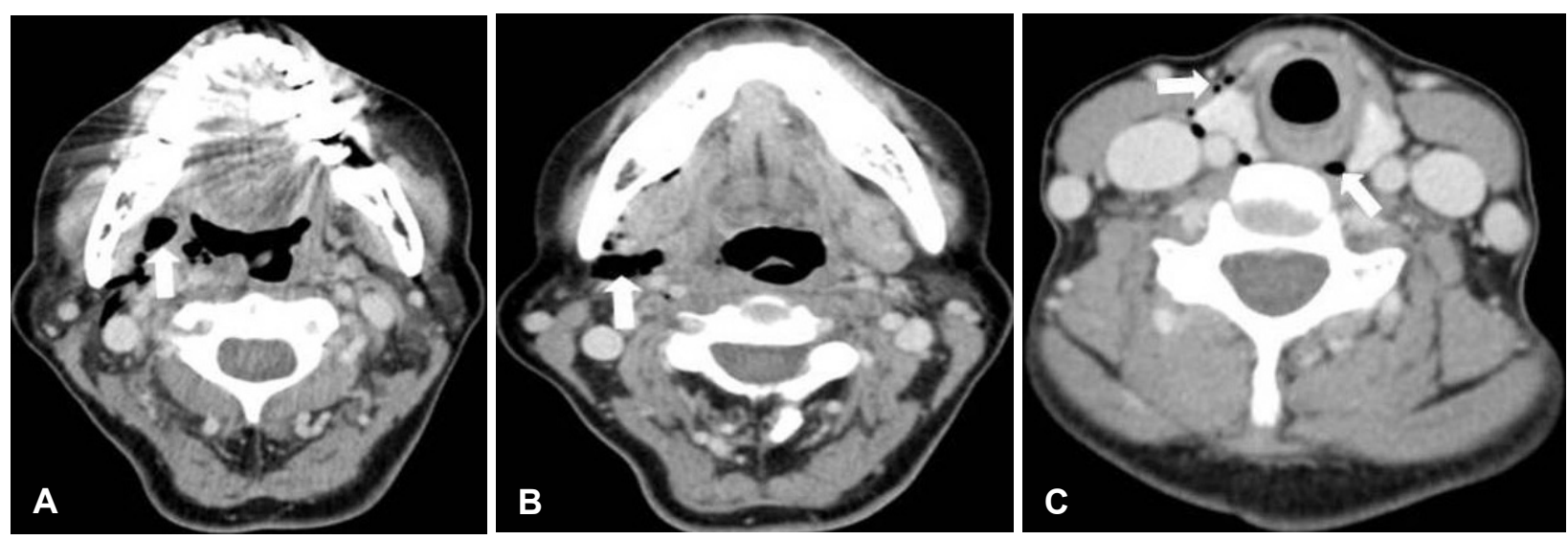

Fig. 1. Neck CT axial view, multifocal air density in right parapharyngeal space (white arrow) (A), right submandibular space (white arrow) (B), right upper paratracheal area (white arrows) (C).

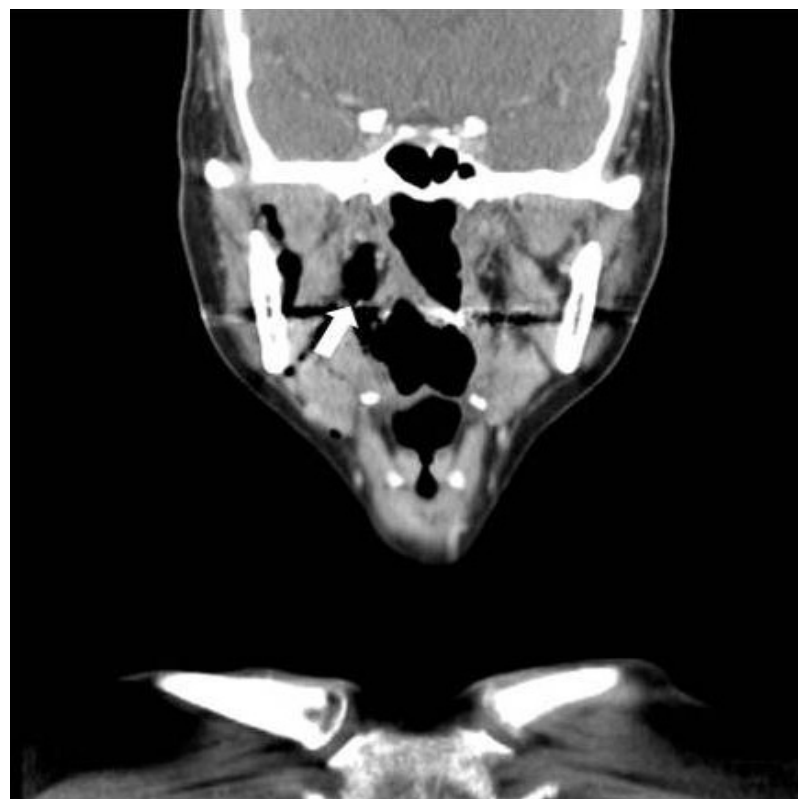

Fig. 2. Neck CT coronal view, suspected tissue defect in right tonsillectomy site (white arrow).

로 생각되는 부위가 관찰되었으며(Fig. 2) 우측 경부에 발생 한 다발성 기종(emphysema)은 이로 인한 것으로 생각되었 다. 환자는 치료적 금식과 함께 정맥을 통한 통증 조절 및 항 생제 치료를 받았으며 수술 후 12 일째 우측 경부의 부종과 마찰음은 소실되었고 다른 특별한 추가적 합병증 없이 퇴원 하였다. 퇴원하여 수술 후 20일째 외래에서 환자의 경과를 다시 확인하였으며 추가적인 특이 합병증은 없었다.

\section{증 례 2}

42세 여자 환자가 평소 잦은 편도염을 주소로 본과에 입원 하여 전기소작술을 이용하여 양측 편도 적출 수술을 시행 받았다. 환자는 수술 후 경미한 인후통 외에 특이 호소 증상 없이 퇴원하였다. 수술 후 5 일째 환자는 심한 인후통 및 연하

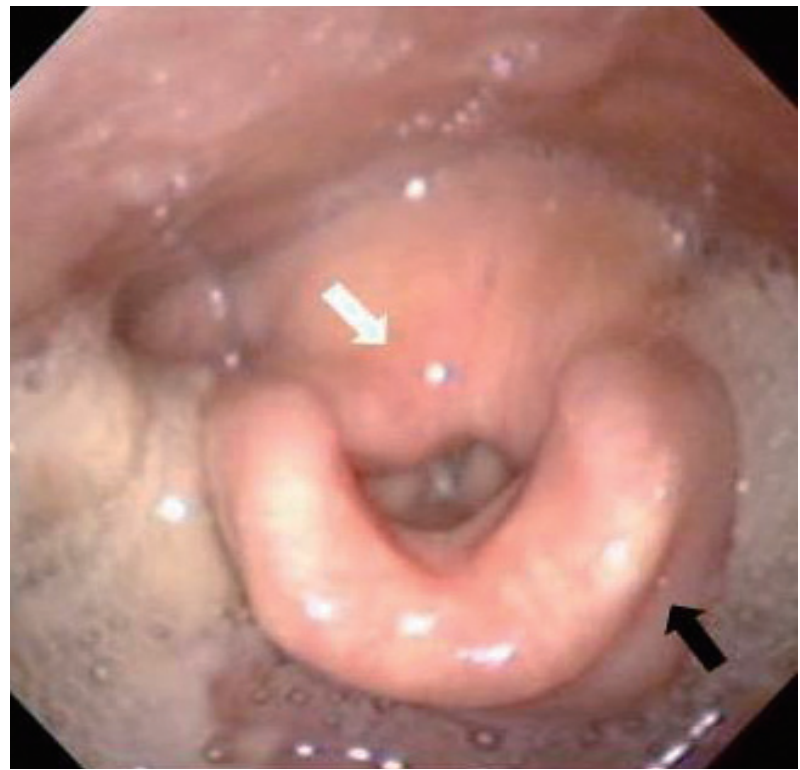

Fig. 3. Flexible laryngoscope view, both oropharynx, hypopharynx, arytenoids (white arrow), and epiglottis (black arrow) swelling was seen.

통을 호소하며 본원 응급실로 내원하였다. 신체 검사 결과 수 술 부위에 특이 소견은 보이지 않았으나 굴곡후두경(flexible laryngoscope)을 이용해 상기도를 관찰한 결과 후두개, 양 측 피열 연골, 그리고 하인두 및 구인두의 부종이 관찰되어 심경부감염을 의심할 수 있었다(Fig. 3).

응급실에서 경부 컴퓨터단층촬영을 시행하였고 그 결과 구인두 및 하인두의 부종과 인접한 양측 인두 주위 공간과 우측 저작근공간으로 다발성 공기 음영이 관찰되었고(Fig. 4) 비록 수술 부위 조직의 결함은 보이지 않았으나 환자의 편도 적출 수술 병력을 바탕으로 하여 편도 적출 수술 이후 발생 한 경부 기종으로 진단할 수 있었다. 환자는 정맥을 통한 통 증 조절 및 항생제 치료를 받았으며 후두개, 양측 피열연골, 그리고 하인두 및 구인두의 부종은 호전된 상태로 수술 부위 

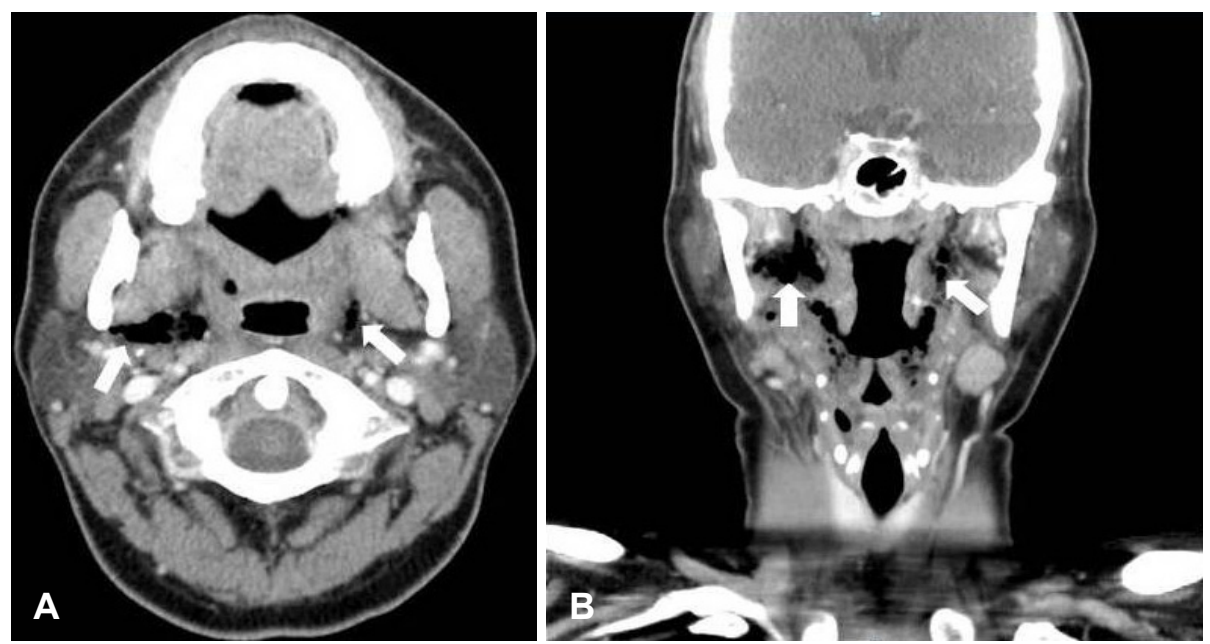

Fig. 4. Multiple air density in both parapharyngeal and right masticator space (white arrows), neck CT axial view $(A)$, neck CT coronal view (B).

에 특이 소견 없이 퇴원하였다. 퇴원 후 7일째(수술 후 15일째) 외래에서 환자의 경과를 다시 확인하였으며 추가적인 특이 합병증은 없었다.

\section{고 찰}

편도 적출 수술 후 발생하는 경부 기종은 매우 드문 합병 증으로 알려져 있다. 이러한 합병증은 수술 혹은 마취 과정 과 연관하여 발생할 수 있는데 수술시 편도의 과도한 박리에 의한 편도와(tonsillar bed) 점막 및 근육의 파열이 원인이 될 수 있다. 특히 어른의 경우 반복적인 편도선염에 의해 편 도와의 과도한 섬유화가 형성되어 있어 수술 과정에서 인두 곁공간(parapharyngeal space) 점막 및 근육의 파열이 드물 게 발생할 수 있고 이 파열을 통로로 하여 공기가 피하조직 으로 유입될 수 있다. 이때 인두 근육 조직이 일종의 게이트 밸브(gate valve) 역할을 하면서 공기가 피하조직으로만 단 향성(unidirectional)의 흐름을 보이게 한다.) 또한 마취 과정 에 발생한 기관내삽관에 의한 외상, 기계 혹은 마스크에 의한 과도한 양압 환기 등이 원인이 될 수 있다.) 그밖에 수술 후 나 타나는 구역질, 구토, 기침, 그리고 발살바 조작(valsalva maneuver) 등에 의해 인두내 압력(intrapharyngeal pressure)이 과도 하게 높아지게 되면 공기의 피하조직으로의 이동이 촉진되어 경부 기종을 유발할 가능성이 있다.

증례 1 의 경우 수술 중, 후에 육안상 특이 소견은 보이지 않았으나 경부 컴퓨터단층촬영으로 우측 편도와 부위에 경 미한 조직의 결함으로 생각되는 부위가 관찰되어 이 조직의 결함이 경부 기종을 유발한 것으로 생각할 수 있었다. 증례 2 의 경우 육안 및 경부 컴퓨터단층촬영으로 양측 편도와 부 위의 조직 결함을 관찰할 수 없었다. 그러나 편도와의 과도한 유착과 섬유화로 인해 수술 후 편도와 부위 인두 점막의 충
분한 위약이 있었을 것으로 생각되며 수술 중 기관내발관 후 시행한 마스크에 의한 과도한 양압 환기와 수술 후 환자의 구역질과 기침에 의해 인두내 압력이 과도하게 높아지면서 위약한 인두 점막을 통한 공기의 피하조직으로의 이동이 촉 진되어 경부 기종을 유발했을 것으로 생각된다.

수술 후 즉시 나타날 수 있는 경부 부종의 경우 수술 후 출 혈, 알레르기 반응 및 혈관신경성 부종 등을 경부 기종과 감 별을 해야 하며 ${ }^{8)}$ 경부 촉진시 발생하는 연발음(crepitus)과 영 상학적 촬영을 통해 경부 기종을 진단할 수 있다.

본 증례의 경우 두 환자 모두 종격동기종이 나타나지는 않 았으나 경부 기종 발생시 인두곁공간과 인두뒤공간(retropharyngeal space)과의 해부학적 연관으로 인해 경부의 공기는 종격동으로 이동할 수 있는 가능성이 있으며 기관을 타고 종 격동으로 공기가 퍼져 종격동기종이 동반될 수 있다. 비록 경 부 기종의 경우 일반적으로 치료가 용이하며 제한적인 합병 증이긴 하나 적절한 진단과 치료를 받지 않을 시 기관 압박, 심막기종, 정맥 환류 이상 및 치명적 저혈압 등 대단히 심각 한 결과를 낳을 수 있다는 점에서 매우 중요하다. ${ }^{4)}$

기흥이나 종격동기종이 동반되지 않은 대부분의 경부 기 종은 치료가 용이하며 추가적 합병증 없이 치료될 수 있다. 공기 소실의 호전 여부와 함께 상기도를 자주 확인하여 상기 도 폐색에 의한 호흡 부전을 예방해야 한다. 심한 연하통을 호소할 경우 정맥을 통한 수분공급과 진통제 투여가 효과적 일 수 있다. 또한 환자는 경부 공기가 소실될 때까지 격렬한 운동이나 기침 등의 행동을 삼가야 하며 구강 내에 존재하는 세균들의 구인두로의 이동에 의한 감염을 막기 위해 경험적 항생제 사용이 추가적으로 필요하다. ${ }^{3)}$ 산소 공급이 질소의 흡 수를 용이하게 하여 회복을 더 촉진시킨다는 보고도 있다. ${ }^{6}$

경부 기종은 편도 적출 수술 혹은 마취 과정과 수술 후 구 역질, 구토, 기침, 그리고 발살바 조작 등의 요인에 의해 복합 
적으로 발생할 수 있는 드문 합병증으로 비록 대개 양성적 경과를 거치지만 공기의 추가적 확대에 의한 심각한 합병증 을 예방하기 위해서는 환자에 대한 신속하고 적절한 진단과 치료가 필요하다.

\section{Acknowledgments}

This research was supported by an Inha University research grant.

\section{REFERENCES}

1) Kendrick D, Gibbin K. An audit of the complications of paediatric tonsillectomy, adenoidectomy and adenotonsillectomy. Clin Otolaryngol Allied Sci 1993;18(2):115-7.

2) Stewart AE, Brewster DF, Bernstein PE. Subcutaneous emphysema and pneumomediastinum complicating tonsillectomy. Arch
Otolaryngol Head Neck Surg 2004;130(11):1324-7.

3) Marioni G, De Filippis C, Tregnaghi A, Gaio E, Staffieri A. Cervical emphysema and pneumomediastinum after tonsillectomy: it can happen. Otolaryngol Head Neck Surg 2003;128(2):298-300.

4) Vos GD, Marres EH, Heineman E, Janssens M. Tension pneumoperitoneum as an early complication after adenotonsillectomy. J Laryngol Otol 1995;109(5):440-1.

5) Fechner FP, Kieff D. Cervical emphysema complicating tonsillectomy with argon beam coagulation. Laryngoscope 2003;113(5):920-1.

6) Miman MC, Ozturan O, Durmus M, Kalcioglu MT, Gedik E. Cervical subcutaneous emphysema: an unusual complication of adenotonsillectomy. Paediatr Anaesth 2001;11(4):491-3.

7) Shine NP, Sader C, Coates H. Cervicofacial emphysema and pneumomediastinum following pediatric adenotonsillectomy: a rare complication. Int J Pediatr Otorhinolaryngol 2005;69(11):1579-82.

8) Hampton SM, Cinnamond MJ. Subcutaneous emphysema as a complication of tonsillectomy. J Laryngol Otol 1997;111(11):1077-8. 